\title{
CONHECIMENTO HISTÓRICO ESCOLAR E NARRATIVAS AUDIOVISUAIS: AMPLIAÇÃO DE ARGUMENTOS NAS FRONTEIRAS ENTRE “HISTÓRIA REAL” E FICÇÃO
}

\section{PATRÍCIA TEIXEIRA DE SÄ*}

Resumo: o artigo aborda a construção do conhecimento histórico escolar em uma escola pública da rede municipal de ensino do Rio de Janeiro. Foram realizadas audiogravações e transcrições de aulas em três turmas de 9 o ano do Ensino Fundamental. Focalizamos, nesse texto, movimentos do circuito didático que se estabeleceu a partir da exibição e debate do filme "Guerra de Canudos". Concluímos que a proposta de aula dialogada, com análise de narrativa fílmica, possibilitou a ampliação e diversificação de argumentos na construção do conhecimento histórico escolar por parte dos estudantes, movimentos que podem ser considerados importantes para fazer frente à concepção de história escolar como narrativa unidirecional e sem ambiguidade.

Palavras-chave: Ensino de História; Conhecimento Histórico Escolar; Cinema; Educação Básica.

Historical knowledge and audiovisual narratives: extension of arguments in the borders between "real history" and fiction

Abstract: the article deals with the construction of historical school knowledge in a municipal public school in Rio de Janeiro. Audio recordings and transcriptions of classes were carried out in three 9th grade classes. The article focuses on the didactics that were established from the viewing and debating of the film "War of Canudos". It concludes that the proposal of a dialectical classroom, with film narrative analysis, allows students to expand and diversify their arguments in the construction of scholarly historical knowledge. This can be considered important to counteract the concept that school history is a one-way narrative and without ambiguity.

Keywords: History teaching; Historical School Knowledge; Movie theater; Basic education.

\section{Introdução}

"É história real?" A professora de História é interpelada dessa maneira por um estudante do último ano do segmento de Ensino Fundamental. Havia sido trabalhada a temática da formação e massacre do arraial de Canudos no final do século XIX no Brasil ao longo de duas semanas anteriores ao questionamento. Ao final do debate sobre o filme "Guerra de Canudos", o estudante pergunta se aquela história "aconteceu mesmo". A dúvida do estudante - que haveria surgido de forma similar em outra turma do mesmo contexto escolar - provoca-nos a refletir sobre as fronteiras entre ficção e "his-

\footnotetext{
* Doutora em Educação pela PUC-Rio. Auxílio financeiro: FAPERJ.
} 
tória real" em processos de construção de conhecimento histórico na escola, principalmente quando se estabelece contato com produtos culturais que não seguem as mesmas regras, nem possuem as mesmas finalidades do conhecimento formal (acadêmico e/ou escolar).

História como ciência, história como disciplina escolar, meios de comunicação e Estado disputam espaço nos objetivos e procedimentos da interpretação histórica. Na escola, essas diferentes lógicas se apresentam e entram em disputa. Na direção de problematizar a construção do conhecimento histórico escolar em sociedades midiatizadas, algumas questões podem ser formuladas. Como essas instâncias "conversam" no meio escolar? Como se coloca, no espaço do ensino de história na escola, a tensão advinda das diferentes leituras sobre o passado possíveis?

O artigo tem o objetivo de apresentar e analisar transcrições de aulas de história em que foram propostos exibição e debate do filme "Guerra de Canudos" (Sérgio Rezende, 1997). Após apresentação da metodologia e do campo empírico, abordarei os movimentos do circuito didático que se estabeleceu a partir do uso pedagógico do referido recurso audiovisual. O propósito é discutir aspectos relacionados à construção do conhecimento histórico escolar, com vistas a estabelecer correlações entre narrativas construídas com mediação de conceitos históricos e narrativas construídas com mediação de produtos audiovisuais.

\section{Metodologia e Campo Empírico}

O estudo foi desenvolvido a partir de observações, áudio-gravações e notas escritas de aulas de história em três turmas de 9 o ano do Ensino Fundamental. Durante três meses, acompanhei três horas/aula semanais em cada uma das três turmas observadas, em dezesseis visitas à escola. O registro do áudio foi realizado através de um gravador digital colocado sobre a mesa da professora. Eventualmente, a gravação captou falas e comentários dos estudantes, mas a voz predominante e clara nos arquivos de áudio é da professora. Nas notas de campo, procurei registrar falas e atitudes dos estudantes diante das propostas didáticas da professora, buscando registrar a heterogeneidade de vozes e atitudes no ambiente da sala de aula. Para análise, estão arquivados 1.381 minutos de aulas gravadas - 276 minutos na turma 1, 520 minutos na 
turma 2 e 585 minutos na turma 3.

Todos os arquivos de áudio e notas de observação foram transferidos para o software Atlas TI. Elaborei, para cada aula gravada, uma sinopse contendo as principais informações sobre o "circuito da aula" ${ }^{1}$. Procurei registrar o tempo destinado ao trabaIho específico com temas da história e marcar os momentos em que a professora ou os estudantes efetuaram alguma análise de conteúdos midiáticos, livros didáticos ou outros materiais propostos. Além desses, estão registrados nas sinopses outros momentos que considerei que influenciam e/ou interferem na construção do conhecimento histórico escolar, tais como interrupções externas por parte da direção, de outros professores, de estudantes, da inspetora etc., demandas diversas dos estudantes, estratégias da professora para gerir o fluxo de interações e manter a disciplina na sala de aula e acontecimentos decorrentes de exigências colocadas pela concretização calendário de avaliações (internas e externas). Nas situações em que há enunciados bem elaborados e com boa qualidade de áudio, sinalizei a necessidade de transcrição para análise mais detalhada.

Para o presente texto, selecionei algumas análises efetuadas a partir da escuta e categorização ${ }^{2}$ de um conjunto de aulas nas quais estavam propostos exibição e debate sobre filme com temática histórica - o longa-metragem "Guerra de Canudos", de Sérgio Rezende (1997).

Em um bairro da zona oeste da cidade do Rio de Janeiro está localizada a escola em que foi realizado o estudo principal deste trabalho. O bairro possui 64.649 habitantes e faz parte da 18a Região Administrativa da cidade, que compreende Campo Grande, Cosmos, Inhoaíba, Santíssimo e Senador Vasconcelos. Ao total, essa zona administrativa possui 542.068 habitantes segundo o Censo 2010. A escola está situada em uma localidade bastante integrada ao bairro de Campo Grande, o mais populoso da cidade do Rio de Janeiro. No entorno da escola, predominam domicílios modestos. A região possui poucos estabelecimentos comerciais, geralmente destinados às necessi-

\footnotetext{
${ }^{1}$ Termo utilizado por Rocha (2006), em sua tese de doutoramento, para designar a "trama de atos, atividades ou experiências rotineiras" que se desenvolve no horário escolar.

${ }^{2} \mathrm{Na}$ medida em que fazia a primeira escuta, produzia sinopses escritas de cada aula. Nas sinopses, procurei registrar o circuito didático de cada aula, ou seja, o tipo de atividade realizada, o tempo dispendido para cada atividade, ocorrências especiais e, eventualmente, diálogos entre professora e os estudantes. Também nas sinopses, sinalizei trechos com bom áudio para transcrição e fiz pequenos resumos dos conteúdos abordados e conceitos trabalhados.
} 
dades locais como minimercados, padarias, restaurantes e bares de pequeno porte. Próximo à escola, há cerca de dez minutos caminhando, encontra-se uma estação de trens vindos da Central do Brasil, no centro da cidade do Rio de Janeiro.

A escola oferece o segundo segmento do Ensino Fundamental e atende a 565 estudantes entre o 6ㅇ e 0 9 anos do Ensino Fundamental. As salas de aula estão equipadas com projetor multimídia, ar condicionado e quadro branco. São aproximadamente 40 estudantes ocupando cada sala de aula. O teto das salas é de material sintético, tipo pvc, através do qual sons, vozes e ruídos passam facilmente. Há um sistema de som com autofalantes, geralmente utilizado pela direção, coordenação e inspeção para diversos tipos de recados - convocação de professores e estudantes para conversas na administração, informações sobre merenda, chamadas disciplinares, objetos perdidos etc.

As turmas observadas possuíam carga horária de três horas/aula - de 50 minutos cada - semanais de história. As turmas I e II pertenciam ao turno da manhã e a turma III, ao turno da tarde, todas elas regidas pela professora Joana [nome fictício]. Essas turmas representam a totalidade dos estudantes que frequentam o 9o ano do Ensino Fundamental matriculados na escola investigada - 41 alunos na turma I, 43 na turma II e 42 na turma III, segundo a lista de chamada da professora. Não registrei nenhuma disparidade de idade entre os estudantes de todas as turmas observadas, que estão dentro do que se denomina "adequação idade/série".

Em relação ao perfil dos estudantes participantes da pesquisa, trata-se de um público com homogeneidade de idade (14 / 15 anos), em sua maioria autodeclarado como pardo ou negro, filhos de trabalhadores do setor de serviços, indústria, construção civil ou trabalho doméstico na casa de outras pessoas, com escolaridade concentrada no Ensino Médio. Esses dados foram produzidos a partir da aplicação de um questionário aos estudantes, com questões sobre perfil socioeconômico ${ }^{3}$ e, mesmo não seguindo todos os critérios e procedimentos de classificação econômica realizados por pesquisas estatísticas especializadas, nos permitem inferir que estamos lidando com estudantes pertencentes às classes C e D.

\footnotetext{
${ }^{3}$ Questões formuladas para apurar informações sobre os estudantes, tais como sexo, idade, pertencimento étnico racial, religião, escolaridade e profissão da mãe e do pai.
} 


\section{A ampliação de argumentos na aula de história: a construção do conhecimento histó- rico escolar com mediação de produtos audiovisuais}

PROF: O que vocês podem chamar a atenção da parte que a gente viu do filme?

- Que eles eram muito burros.

PROF: O que?

- Que eles eram burros pra caramba.

PROF: Por que?

- Porque, ao invés de fazer a parada em frente a um rio, não, foram fazer no meio da seca.

PROF: Mas olha só.... Você acha que rio é assim? Tipo, êêêê tem um rio aqui e...

- Eu tô brincando, professora.

PROF: Pois é. Porque é isso que falei. Onde tem um açude, onde tem qualquer tipo de água potável, pode ter certeza que aquilo vai ficar na terra de um coronel e aí ele não ia poder montar.... Aquela terra onde foi montada a comunidade, se não me engano, era uma terra que estava meio abandonada, assim...

Trata-se de uma colocação feita por um estudante na aula de história, em meio às discussões sobre a questão fundiária e os movimentos messiânicos no Brasil do início do período republicano. A professora de história havia exibido o filme "Guerra de Canudos" na aula anterior e procurava sensibilizar a turma para a situação do sertanejo no Brasil na virada do século XIX para o XX. O conteúdo escolar em desenvolvimento era a formação do arraial de Canudos e os motivos que levaram ao massacre da população. Os estudantes da turma II, em questão, haviam assistido a uma aula expositiva sobre o tema. A seguir, assistiram aos vinte minutos iniciais do filme mencionado na sala de aula, através de um projetor multimídia. A professora, antes da exibição, perguntava: "mas a seca era só uma questão da natureza?" Insistia: "quais eram os principais problemas do sertão?" E justificava que o filme poderia "dar uma imagem daquilo que a gente falou".

$\mathrm{Na}$ aula destinada ao debate sobre o filme, durante trinta minutos, professora e estudantes travaram diálogos sobre o tema Canudos. Os comentários dos estudantes envolviam, ao mesmo tempo, impressões sobre a aula, sobre o conteúdo curricular abordado e sobre o filme: "o lugar ainda existe?", "se existe, deve ser patrimônio histórico", "mas a igreja não era dona de quase tudo?", "havia negros no sertão? ", "professora, isso aconteceu mesmo?", "o que aconteceu com a moça que fugiu? ", "o filme 
era preto e branco?", "o filme é muito laranja". Em suas narrativas e respostas, a professora recorre a conceitos como movimento messiânico e banditismo social, historiciza a distribuição de terras e de água, lê um trecho do livro didático que trata das ruínas da igreja construída no arraial de Canudos, diz que a Igreja Católica não era dona de tudo - que provavelmente eles estão fazendo referência ao período da Idade Média, estudado anteriormente -, cita uma música do compositor pernambucano Chico Science, situa o período da formação de Canudos enfatizando o fato de que a escravidão havia sido recentemente abolida no Brasil, fala de racismo...

PROF: Eles tinham armas. Mas tinham muito menos do que o exército brasileiro.

- Aquelas espingardas com ponta, né professora? [aluno]

PROF: É. E aí, na quarta tentativa, milhares de soldados foram para cima. $E$ depois de uma batalha que durou muito tempo, finalmente... na verdade, foi um massacre. Foi um massacre. É triste, na verdade.

- Não aparece, no filme, esse massacre. [aluno]

PROF: Aparece, no final. Na verdade, assim, o filme mostra a condição do sertanejo, aquela coisa pobre. Tu vê ali naquela família, por exemplo, eles ficam numa situação... Eles estavam comendo pombo, sei lá que bicho era aquele. E o pouco que eles tinham, que era aquela vaca, tiveram que vender. $E$, mesmo assim, um cara, um representante da república chegou e tomou. Então, ele recebeu pela vaca, adiantado, e nem tinha mais a vaca para poder... enfim, eles não tinham o que fazer. Aí o Antônio Conselheiro, ele estava ficando conhecido, ele já tinha uma fama. Há anos, há quase dez anos que ele já estava nessa pregação. Ele ia de cidade em cidade, na verdade ele tinha vindo do Ceará. E aí ele começou a adquirir uma fama de ser santo. Porque ele consertava cemitério, ele erguia igreja, ele limpava cemitério.

- Todo mundo tinha medo de limpar cemitério?

PROF: Sei lá, porque era abandonado. Ele tinha as atividades religiosas. Ele sempre tinha uma palavra para dar para a população mais pobre. E, como eu disse, era uma religiosidade muito mais próxima da população. Não era aquela coisa, o padre lá e o resto da hierarquia da igreja católica que mal tinha contato. Não! Ele estava ali, pé no chão.

- Meio pobre. [aluna]

PROF: É. Ele não tinha ligação com os grandes proprietários de terra. Tipo, a Igreja Católica, legitimava o poder dos coronéis, como a gente já conversou. A gente viu isso no filme $O$ Auto da Compadecida. $O$ padre puxando o saco do coronel, o bispo puxando o saco do coronel.

- Mas a Igreja Católica não era dona de quase tudo? [aluna]

PROF: Não, gente. Isso é...

- Isso é na Europa, né? [aluno]

PROF: Isso aí é quando a gente estudou feudalismo, Idade Média. 
Não que a Igreja Católica não tivesse poder aqui no Brasil, tinha também, mas não como a gente imagina a Igreja Católica na época da Idade Média. Uma coisa que eu acho que vale a pena a gente conversar, é que tem uma cena que ele chega lá na cidade e tem uma velhinha falando que não ia pagar imposto, que não sei o quê. Porque ele tinha o discurso político antirrepublicano que era...

- O povo para e aplaude, êêê!! [aluno]

PROF: Que para ele o motivo de todos os males, de todas as pessoas, era a república, tá? Claro, gente, que não era bem assim. Aquela situação de injustiça social já existia antes da república, tá?

- E sempre vai existir. [aluno]

PROF: Mas, por exemplo, ele chegou lá, uma hora, e falou assim: veja essa senhora. Ela não tem que pagar imposto mesmo não, porque o imposto não volta para gente. Vai pagar imposto para que? E aí ele fala: veja essa senhora, ela é branca, religiosa. Por que ele fala isso? Que ela é branca?

- Porque ela não é negra. Porque ela não é escrava. [aluna]

PROF: Por que ele tem preconceito racial? Por quê? Vamos ver. A gente está em 1893. A escravidão tinha acabado há cinco anos.

- Mas ainda tinha muito escravo. [aluno]

PROF: Então, naquela época, liberdade, ser livre era uma característica de branco. Porque os negros eram escravos. Então, não é que ele está dizendo que só merece ser livre quem é branco.

- Não vi nenhum neguinho. [aluna]

PROF: Depois aparece. Um dos mais aguerridos.

- Eu tava olhando assim, eu falei: não tem nenhum negro. [aluno]

PROF: Mas depois aparece. Mas isso, Jeremias, isso que você perguntou, foi uma coisa que eu mesma fiquei me perguntando: não tinha negro no sertão da Bahia não?

- Na Bahia, é onde tem mais preto. [aluno]

- É negro! É raça. É afro americano. [aluno]

PROF: Gente, eu não tenho problema de falar preto. Eu particularmente não tenho. Não se fala branco? Por que não falar preto? É porque a gente tem mania de achar que preto é necessariamente uma coisa ruim. Para mim, não é. Então, tipo assim, eu falo preto. E daí? É legal.

- É racismo! [aluno]

PROF: Eu não acho que é racismo.

- Eu também não acho, professora. [aluna]

PROF: Porque é racismo se você está querendo usar isso como uma coisa pejorativa. Agora, se eu falar fulano de tal é preto. Ok, eu não falo que eu sou branca? Por que não posso falar que ele é preto? Eu estou falando que é ruim ser preto? Não, acho ótimo, acho lindo, maravilhoso.

- Elas estavam brincando aqui: por que a Júlia não pode ser amarela? Eu chamei ela de Simpson. Ela é Lisa Simpson, parece muito. [aluno].

O espectro de questões se amplia e ultrapassa o debate inicial sobre o antirrepublicanismo do movimento de Canudos. A professora propõe a análise da cena em que uma personagem idosa e branca se recusa a pagar impostos e um aluno comenta 
que percebeu a ausência de personagens negros no filme. Começa a organizar argumentos em torno do contexto pós-abolição no Brasil e é interpelada por outros comentários de estudantes sobre o problema do racismo e das terminologias utilizadas para designar pessoas negras no Brasil. Outro estudante diz que o estado da Bahia possui grande contingente de população negra, ensaiando um estranhamento pela ausência de personagens negros no filme. Ao final do trecho, outro aluno brinca com uma colega, associando-a a uma personagem de um desenho animado.

Vejamos um trecho do desenvolvimento da mesma atividade na turma I. A professora começa justificando a ideia da aula: por se tratar de um filme muito longo, com três horas de duração, ela pretende "falar um pouco, passar umas cenas do filme". Situa o debate no programa curricular, lembrando a todos que estão "entrando nessa unidade de movimentos sociais na república" e que trabalharão revoltas urbanas e rurais no período da República Velha. Joana faz uma narrativa sobre a pregação de Antônio Conselheiro no Nordeste, introduz o tema dos movimentos messiânicos, comenta o antirrepublicanismo e o anticatolicismo do movimento de Canudos e o desafio que a comunidade representava ao coronelismo e à concentração de terras. A professora finalizou sua narrativa sobre Canudos com dados "objetivos": "Então, Belo Monte começou a crescer, crescer, crescer, em pouco tempo mais de 20 mil pessoas, alguns historiadores falam que Canudos chegou a ter 30 mil moradores, que é muita gente, se for pensar na quantidade de pessoas que viviam naquele tempo" e isso parece ter levado um dos alunos a se dar conta de que o que o filme tratava de acontecimentos históricos.

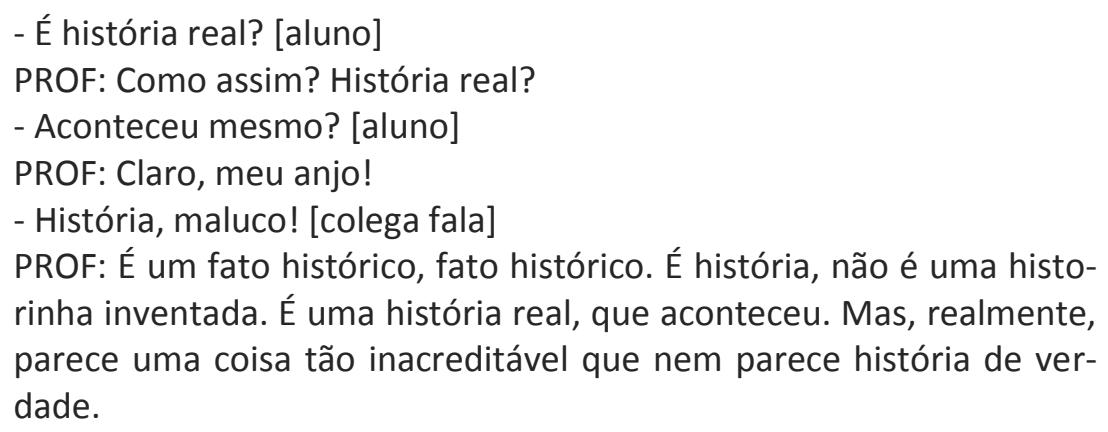
rinha inventada. É uma história real, que aconteceu. Mas, realmente, parece uma coisa tão inacreditável que nem parece história de verdade.

Finalizada essa introdução, a professora exibe vinte minutos iniciais do filme. Propõe análises de trechos do filme, estabelecendo relações entre essa narrativa audiovisual e o programa curricular e ensaiando algumas análises de cenas do filme: 
PROF: Olha só, por esse pedacinho deu para a gente ver algumas partes interessantes, que tem a ver com a história que a gente falou nas últimas aulas. A situação do sertanejo, não só em relação à seca, mas principalmente em relação à falta de oportunidades no meio rural. Não sei se vocês perceberam, mas aquela figura que compra as vaquinhas, ele seria um coronel. Então assim, a família que aparece ali ainda tinha lá a sua terrinha, só que a seca fez com que eles não conseguissem produzir nada. Agora, a gente precisa ter a ideia também que a seca é uma coisa relativa. Aparece um cara lá falando "ah, mas a seca é uma coisa natural", parece que contra a seca ninguém pode lutar. Então veio a seca, então ninguém pode fazer nada contra isso, como se fosse só um problema da natureza. Só que a seca não atinge os grandes proprietários da mesma maneira como atinge os pequenos proprietários. Porque mesmo nos lugares onde existe a seca, existem formas de você lidar com a seca, tá? Tem lá os açudes nas regiões mais secas do sertão do Nordeste. Com certeza, são lugares onde tem lá um reservatório de água. Certamente, esses lugares ficam dentro da propriedade de quem?

- Dos coronéis [aluno]

PROF: Do pequeno proprietário é que não é. Então, a situação é de exploração, é de seca, mas sem muita vontade pública de resolver a questão da seca, de melhor distribuir a água. Não estou dizendo que a seca não existe, como uma invenção, mas existe muito mais uma má distribuição da água, tá? Então deu para a gente ver mais ou menos como era a vida do sertanejo pobre, o cara ficou sem nada. Enfim, deu para a gente ver também a própria figura do Antônio ConseIheiro, que a gente fica falando. Tudo bem que é um filme, o cara que fez o filme faz a figura de acordo com o que vem na cabeça dele, né? Outras pessoas fariam diferente. Mas é mais ou menos isso. Era um cara que andava de camisolão, com uma barba grande, pregando a palavra de deus, mas sem ter um vínculo com a igreja católica, mas que ele falava principalmente contrário à república. Então o discurso dele era contrário à proclamação da república. Aí tem uma parte que é bom a gente chamar a atenção: tem uma velhinha que fala que não é bom pagar imposto, porque a gente não recebe nada em troca. Então ele fala: veja essa senhora, ela é branca, ela trabalha"'. Por que ele fala isso? Que a senhora é branca? Porque a escravidão tinha acabado de acabar, né? Então, assim, o ser livre para ele ainda era uma coisa de branco, os negros eram associados à escravidão. Então, assim, não foi exatamente um pensamento preconceituoso dele, foi um pensamento que tem a ver com a época que ele está vivendo. Ela é uma pessoa, ela é livre e ela é branca, ou seja, ela não é escrava e ela está sendo tratada como uma escrava.

- Durou quanto tempo, professora? Durou quantos anos?

PROF: Então, foi fundado em 93. Não tem aquela parte que ele fala, e claro que tem as coisas que a gente não tem certeza se realmente ele disse isso, ele faz tipo uma profecia. Ele era considerado um profeta. Ele faz uma profecia, não sei se vocês repararam, que virão quatro fogos contra ele. "Os três primeiros serão meus. O quarto fogo, só deus sabe qual será". É uma alusão a que? Às guerras que vão ser implementadas contra Canudos. Então os três primeiros, eles realmente ganham. O quarto foi quando Canudos foi arrasado em 1897. 
Mas aí, na aula que vem, amanhã...

- Ah, então durou pouco, Canudos... 93 a 97... [aluno]

- Qual é o nome desse cara aí? [aluna]

PROF: Antônio Conselheiro?

- Não, o nome dele na história. [aluna]

PROF: Antônio Conselheiro ou nome do ator?

- É, desse homem. [aluna]

PROF: O nome do ator? José Wilker

- Professora, a derrota foi quando? [aluno]

PROF: 1897. Quatro anos depois. Gente, alguém tira os fios aí para mim.

A professora ensaia o mesmo direcionamento dado à turma II, procurando analisar a personagem idosa e branca que se recusava a pagar imposto e a cena da família que perde o gado. As questões dos estudantes foram em outra direção. Os alunos pareciam intrigados com a veracidade ou não da história narrada no filme. A professora, inicialmente, exibiu o filme com intenção de promover uma visualização da situação do sertanejo no período estudado. Em certo ponto do debate, foi necessário deixar claro que "é um filme, o cara que fez o filme faz a figura de acordo com o que vem na cabeça dele, outras pessoas fariam diferente". Mas, na sequência, confirma a aproximação entre a construção estética do Antônio Conselheiro no filme e a verdade histórica, dizendo: "mas é mais ou menos isso, era um cara que andava de camisolão, com uma barba grande, pregando a palavra de deus, mas sem ter um vínculo com a igreja católica, mas que ele falava principalmente contrário à república". Uma aluna ainda parece confusa ao perguntar o nome "desse cara", se referindo ao ator que representa Antônio Conselheiro.

É interessante também ressaltar que o filme em questão tem duração de três horas e uma grande parte destinada às batalhas travadas entre os exércitos baiano e federal e os habitantes do Arraial de Canudos. Os estudantes verbalizam algumas dúvidas em relação ao filme, mas a professora realiza análises em diálogo com conceitos históricos e com a narrativa do livro didático sobre o tema ${ }^{4}$.

Na turma III, as dinâmicas em torno do filme tomaram uma direção muito diferente dos dois últimos casos. A turma assistiu a trinta e seis minutos do mesmo filme, os estudantes copiaram textos sobre a formação do arraial de Canudos e sobre a Guer-

\footnotetext{
${ }^{4}$ No capítulo do livro didático destinado ao tema Canudos, são explicitados os conceitos de messianismo, cangaço e banditismo.
} 
ra do Contestado. Depois da exibição do trecho escolhido, uma única pergunta foi dirigida à professora: "Professora, Canudos era um povo ou uma terra? ". A atividade transcorria em meio à semana de provas bimestrais. Joana pergunta à turma: "O que Canudos e Contestado têm em comum? " Segue-se um silêncio, uma aluna diz que as provas estão confundindo a sua cabeça e que não consegue pensar. A professora responde que compreende, mas que vai iniciar uma revisão e depois vai escrever uma matéria no quadro e eles poderão ficar mais tranquilos depois disso. Joana retoma a discussão sobre organização e propriedade de terra. Depois de nove minutos explicando, dirige uma pergunta à turma:

PROF: Alguém já ouviu falar do cangaço? Alguém já ouviu falar de cangaceiros?

- Eu já! Na novela... [aluna]

- Eu já, eu já [aluno]

PROF: Teve uma novela né? Então, assim, hoje a gente vai começar. Como vocês estão aí todos [ansiosos por causa da prova]... e eu também quero acabar de corrigir a prova, eu vou escrever o texto no quadro e depois a gente vai conversar com mais calma. Mas, dando o pontapé inicial, quando a gente fala de cangaço, de cangaceiro, o que vem na mente de vocês? Daniela, que viu a novela, por exemplo?

- Aquele cara que usa roupa de couro. Roupa feia! [aluna]

PROF: Oi?

- Roupa feia! [aluna]

PROF: Gente, não dá para a gente pensar com o nosso gosto, com a nossa referência do que é bonito, uma roupa que se usava há cem anos, em um lugar diferente. Mas o que vem na cabeça, além dessa roupa feia que a Daniela falou?

- Gostava de matar pessoas. [aluna]

- Disputa dos cangaceiros com os coronéis. [aluno]

- Faziam justiça com as próprias mãos. [aluno]

PROF: Mais o quê?

- Não gostava de polícia [aluno]

PROF: Bom, na verdade tudo isso que vocês falaram, tirando a roupa feia que é uma questão de gosto, tudo que vocês falaram tem alguma coisa a ver. Pelo menos tem a ver com o imaginário existente em relação ao cangaço. $O$ cangaço foi um fenômeno típico da região nordestina no Brasil, tá? Alguns estudiosos atrelam o cangaço ao movimento que chamam de banditismo social. Esse nome diz alguma coisa para vocês? Banditismo social? O que esse nome tem? O nome diz alguma coisa para vocês?

- Bandido que defende a sociedade, professora? [aluno]

- Bandidos com classe [aluno]

- Bandidos tipo milicianos [aluno]

PROF: Tipo milicianos? Eu acho que parece mais com traficante do que com miliciano. Mas tudo bem, pode ser. Não, acho que não. Acho que miliciano não entra nesse negócio não. 
- Bandido que defende a sociedade, professora. [aluno]

PROF: Isso é uma coisa complicada mesmo para o nosso pensamento alcançar. Mas a gente pode, a partir de hoje, começar a pensar sobre isso. O fenômeno, digamos assim, do banditismo social foi analisado por alguns estudiosos e não é restrito ao cangaço. Seria um fenômeno possível de observação em vários países e que, assim, resumindo bastante, é um tipo de crime, de formação de criminalidade. Realmente, são pessoas fora da lei, pessoas que estão à margem da lei. Mas que a marginalidade dessas pessoas, o fato dessas pessoas estarem fora da lei seria causada por uma questão social. No nosso caso, no caso do cangaço, o fato das condições adversas no Nordeste no período, tudo isso que a gente já falou, má distribuição de terra, pobreza, miséria, as pessoas passando fome, a opressão dos coronéis. Tudo isso é problema social, certo? É um problema social, um problema que se abate na sociedade e prejudica a vida dos indivíduos. Então o banditismo social teria como base, como causa essas questões sociais, tá? Lembra quando a gente viu aquele filme $O$ Auto da Compadecida?

- Hã? [aluna]

- Posso ir ao banheiro? [aluno]

PROF: Pode. Ih, gente, hoje vocês estão meio mais ou menos, não?

- Posso beber água? [aluna]

PROF: Espera ele voltar? Hein, galera? Lembra daquele filme, O Auto da Compadecida, que tinha um cangaceiro? Lembra?

- Loucão aquele filme. [aluna]

PROF: Lembra do filme loucão? Que o cangaceiro era mau, matava todo mundo, ele chegava na cidade para roubar, para saquear e matava todo mundo indiscriminadamente. Porque existe também uma romantização da figura do cangaceiro. Por exemplo, os cangaceiros da novela eram romantizados. O personagem principal da novela era um cangaceiro. Só que aquele cangaceiro da novela era gente boa pra caramba. Ele não matava ninguém, ele tinha uma coisa de tirar dos ricos para dar para os pobres. Então assim, existe uma romantização do cangaço, como se o cangaço fosse apenas isso. Oh, são pessoas que buscavam justiça social e saíam por aí roubando dos ricos para dar aos pobres e os pobres nunca eram vítimas desses cangaceiros. Não é bem assim. [o ruído de conversas paralelas aumenta significativamente]. Gente!!! [irritada] Ih...

A professora interrompe a explicação, irritada com a dispersão da turma. No dia seguinte, retoma o assunto:

PROF: O que era o cangaço? Quem eram os cangaceiros? Vamos gente! Ontem vocês falaram algumas coisas, da novela... eram grupos armados...

- Que viviam fantasiados. Que viviam para matar. Não tinham pena. [aluna]

PROF: É um fenômeno típico do Nordeste. Era formado por homens e mulheres. Os homens eram maioria, mas também tinham mulheres. Que tinham como prática o saque, o roubo. Eles viviam à margem da 
sociedade. Eram bandos reconhecidos como criminosos. Agora, existe... Gente!! Gabriel! Raquel! Já está o maior barulho lá fora, é difícil chegar a essa hora e ter que ficar falando tão alto! Então, existem várias imagens relacionadas aos cangaceiros. Tem aquelas imagens de que eles eram simplesmente bandidos, pessoas ruins, pessoas do mal, que queriam sair por aí matando porque nasceram para fazer isso, né? $\mathrm{E}$ tem aquelas pessoas que também romantizam os cangaceiros como, por exemplo, na novela que a Daniela lembrou. Como era o nome da novela?

- Cordel Encantado. [aluna]

PROF: Cordel Encantado. Os cangaceiros da novela eram tratados como heróis, eles roubavam dos ricos para dar para os pobres.

- Eu já vi um desenho do pica-pau que era assim. É sério!

PROF: Mas era a história do Robin Hood, né? Na verdade, existe essa associação. Alguns estudiosos, algumas pessoas que refletiram sobre o assunto, escreveram e pensaram sobre o cangaço, pensaram o cangaço dessa forma. Como sendo justiceiros, que roubavam dos ricos e não mexiam com os pobres. Mas, na verdade, o cangaço é um fenômeno muito mais complexo, muito mais complicado do que isso. Nem era apenas um grupo de gente má, que só faz o crime porque gosta. E também não eram heróis que pensam em justiça social e que simplesmente querem repartir as riquezas, tá? Na verdade, vários estudiosos do cangaço atrelam a questão do cangaço a uma coisa chamada banditismo social, um fenômeno chamado banditismo social. 0 que seria o banditismo social? Seria aquela criminalidade, aquelas pessoas fora-da-lei, aquele tipo de criminalidade que tem como fundo um problema social. A pessoa fica à margem da lei e comete crimes por uma questão social. Ou seja, essas pessoas ou esses grupos seriam frutos de problemas sociais. Eu tentei conversar com vocês sobre isso ontem... lembra, Maria Eduarda, Raquel, que vocês falaram 'filme estranho', O Auto da Compadecida. No final desse filme, não sei se vocês lembram dessa parte, vai ter um julgamento. Os cangaceiros invadem a cidade. $O$ filme mostra a figura do cangaceiro não fazendo distinção entre o pobre e o rico, tanto que eles matam tanto o padre, o bispo, o padeiro e a mulher do padeiro, que eram de classe social boa, mas também matam o João Grilo que era aquele mais pobre e mais ferrado.

Nos fragmentos transcritos acima, os conceitos de banditismo social e cangaço são trabalhados a partir de diversas referências audiovisuais. A professora articula dois filmes, uma novela e comentários sobre estudos acadêmicos sobre o conceito de banditismo social. É especialmente desafiador para ela, nesse episódio, lidar com a construção da empatia histórica - compreender o outro, a partir da visão do outro, em seu contexto histórico. "Roupa feia!", "que viviam fantasiados. Que viviam para matar. Não tinham pena", "gostava de matar pessoas" foram algumas colocações dos estudantes a respeito dos cangaceiros. A professora fez um investimento de analisar as 
diferentes referências e relativizar as interpretações, procurando historicizar a construção do imaginário sobre o cangaço, através das "várias imagens relacionadas aos cangaceiros". Utilizou o conceito de banditismo social e recorreu ao exemplo dos narcotraficantes no contexto atual.

Foram duas semanas destinadas ao desenvolvimento do tema Canudos para as três turmas observadas, em seis horas/aula para cada turma. A professora planejou aulas expositivas, exibição de trecho de filme, debate sobre o filme, exercícios escritos e cópia de textos escritos no quadro branco. As turmas assistiram a trechos iniciais do filme, com durações diferentes, a depender da turma, do tempo de aula disponível, do tempo destinado à instalação do equipamento, do tempo da introdução da aula - explicações, justificativas e negociações, das interferências externas e da agitação da turma. As justificativas para a exibição do filme giraram em torno da necessidade de visualizar aquilo que já tinha sido falado na sala de aula.

$\mathrm{Na}$ turma II, com a qual a professora afirma ter grande afinidade, os estudantes respondem aos seus argumentos com comentários e perguntas em grande quantidade e qualidade. Já a turma III, a interação em torno dos conceitos históricos foi muito pequena no período em que estive realizando as observações. A exceção foi o momento posterior à exibição do filme "Guerra de Canudos", em que os estudantes passaram a ter mais recursos para mobilizar seu imaginário histórico e deliberar alguma atenção à aula de história, aumentando significativamente o tempo de aula expositiva e a interação com os conceitos históricos.

Os registros das observações de aulas indicam que Joana apresenta um conjunto mais ou menos planificado de apostas didáticas. Sua metodologia de ensino está bastante pautada na discussão de conceitos-chave que possibilita o debate de situações históricas. Nas aulas em torno do tema dos movimentos rurais no início da república no Brasil, um recurso audiovisual foi proposto. A professora verbaliza seu objetivo de promover uma "visualização da vida do sertanejo", sem oferecer qualquer informação sobre a ficha técnica do filme ou do contexto de sua realização. É articulado um conjunto de conceitos históricos, no entanto, sua fala foi mais interpelada por questionamentos dos estudantes em relação à veracidade da narrativa. De fato, a professora argumentava recorrendo a elementos da aula expositiva anterior - "verdade" - e a análises de cenas do filme - "ficção". A construção narrativa mediada pelo programa 
curricular e a narrativa fílmica se mesclaram no debate sobre o filme e os estudantes apresentaram algumas inquietações sobre as fronteiras entre a ficção e a realidade. 0 filme, nas aulas observadas, até então não havia sido configurado como fonte nem evidência para a história. Diante das dúvidas verbalizadas pelos alunos, a professora menciona que se trata da visão de um diretor e, em seguida, confirma que a construção desse diretor se aproxima "daquilo que ocorreu".

A partir desse circuito de argumentos, a noção de verdade histórica foi trabaIhada por outro caminho, para além da oposição entre verdadeiro e falso. $O$ tratamento dado ao problema, com citações aos narcotraficantes, aos filmes e à novela se aproxima mais do movimento direcionado de confronto de evidências da história, quando há uma preocupação deliberada em contextualizar fontes, situações e interpretações sobre a história. Pode-se afirmar que os recursos audiovisuais, nesse caso, estimularam estudantes a colocarem questões para a história, oferecendo um meio para que verbalizassem suas ideias prévias frente às perguntas da professora. Assim, a dimensão estética da cultura histórica se apresentou como fundamental para a configuração da atividade de ensino na direção da crítica da narrativa unidirecional sobre o passado.

É possível afirmar que questões de empatia histórica e relações estéticas com o passado estiveram associadas nesse processo, na medida em que, a mobilização de argumentos morais como "não tinham pena", "gostavam de matar pessoas" serviram de base para a intervenção da professora no sentido da compreensão do outro em seu contexto histórico, mediada pela história como conhecimento sistematizado e com maior amplitude crítica. Esse movimento resultou em um rompimento com práticas, relativamente comuns nas aulas observadas, de abordagem da história sem ambiguidade.

Fronza (2012) estudou a relação entre o poder narrativo das histórias em quadrinhos e as ideias de intersubjetividade e verdade histórica de estudantes do ensino médio e observou que jovens mobilizaram valores estéticos da cultura histórica quando não estavam seguros de seu próprio conhecimento, tendendo a reproduzir o discurso do professor ou a mobilizar memória de contato com produtos da cultura histórica.

Na visão dos estudantes que participaram desta pesquisa, as narrativas da professora e do livro didático são as mais confiáveis, no entanto, elementos de suas expe- 
riências audiovisuais aparecem em suas falas quando são questionados a respeito de determinados conceitos. A professora iniciou a atividade de ensino com objetivos mais modestos do que, ao final, a aula se transformou. Os estudantes propuseram rotas de desvio da aposta inicial da professora. Atitudes como ironia, moralização, indignação, valorização constituíram reações da professora frente aos comentários dos alunos, todas relacionadas ao contexto de enunciação. A primeira reação da professora foi moralizante - "não dá para a gente pensar com o nosso gosto, com a nossa referência do que é bonito, uma roupa que se usava há cem anos, em um lugar diferente". Depois, os argumentos foram se diversificando e, para tal tipo de intervenção, provavelmente a formação qualificada da professora contribuiu não em termos de história substantiva - apesar da sua importância para qualificar competência - mas sobretudo em termos conceituais.

A experiência prévia dos estudantes na disciplina história, algumas vezes, os levou a algumas tentativas de associação de conteúdos passados frente ao novo, nem sempre coerentes, mas que chama a atenção para uma operação reflexiva atravessada tanto por mecanismos cognitivos quanto pela lógica curricular. É possível que Joana tenha interpretado algumas colocações dos estudantes como tentativas de construir "espaços de burla", sem intenção de construção de conhecimento. Estudantes também têm experiência prévia em se opor à autoridade do professor, com olhares evasivos, posturas corporais que denotam indiferença, "zoação", risos... Atitudes que podem ser consideradas como indicadores de uma cultura contra-escolar ${ }^{5}$.

\section{Considerações finais}

Nas sociedades complexas, os meios de comunicação não são apenas tecnologias que as instituições ou indivíduos adotam ou não. Segundo Hjarvard (2012), a mídia exerce tão significativa influência que ela se tornou parte da lógica de outras instituições, apesar de já ter atingido algum grau de independência e autodeterminação. Ou-

\footnotetext{
${ }^{5}$ Ver clássico estudo: WILLIS, 1991. Para Willis, a cultura contra-escolar - exemplificada por diversas estratégias de oposição à autoridade na escola - é apresentada pelos meios de comunicação e pelos agentes educacionais como indisciplina, violência, desinteresse. $O$ estudo apontou para a experiência cotidiana dos estudantes - "o chão da fábrica" - como espaço de configuração de vários tipos de resistência à lógica escolar.
} 
tras instituições, como família e escola, primordiais na socialização das novas gerações, estão atravessadas, em maior ou menor grau, pela lógica ${ }^{6}$ da mídia. 0 argumento de Hjarvard é que "a mídia é, ao mesmo tempo, parte do tecido da sociedade e da cultura e uma instituição independente que se interpõe entre outras instituições culturais e sociais e coordena sua interação mútua" (2012, p.55). A partir dessa perspectiva, é possível vislumbrar o importante papel que os meios de comunicação exercem na produção e na difusão do conhecimento e interpretações históricas. Weingart, citado por Hjarvard, vê os meios de comunicação como espaço para a discussão pública e legitimação da ciência, influenciando em grande medida a formação da opinião pública, da consciência e da percepção (Weingart, 1998 apud Hjarvard, 2012).

Segundo Hjarvard, "os modos nos quais os meios de comunicação intervêm na interação social dependem das características concretas do meio em questão, ou seja, tanto das características materiais e técnicas quanto das qualidades sociais e estéticas" (HJARVARD, p.75). No caso do filme "Guerra de Canudos", a alta qualidade da fotografia e o caráter de grande produção - foi o filme com maior orçamento até então na história do cinema no Brasil - podem ter configurado grande influência sobre as percepções e interpretações dos estudantes em relação ao fenômeno estudado ${ }^{7}$.

Se admitirmos que a midiatização é um processo em que os meios alteram a "textura da experiência" (Silverstone, 2002) e as relações e comportamentos humanos, então é preciso compreender e admitir a presença desse processo na produção do conhecimento escolar, nesse caso específico, do conhecimento histórico escolar.

\footnotetext{
${ }^{6}$ Hjarvard lembra que midiatização não é um conceito a ser aplicado de maneira universal, não deve ser normativo e não deve ser visto como um problema, a priori. "O termo lógica da mídia refere-se ao modus operandi institucional, estético e tecnológico dos meios, incluindo as maneiras pelas quais eles distribuem recursos materiais e simbólicos e funcionam com a ajuda de regras formais e informais" (2012, pp.64-65).

7 Para uma análise historiográfica do filme "Guerra de Canudos" (Sérgio Rezende, 1997), ver artigo "Imagens de Canudos", de Jacqueline Hermann. A autora situa a produção no contexto do centenário da destruição do Arraial de Canudos e explicita duas principais correntes que procuraram "explicar" Canudos: a "euclidiana", com base no livro Os Sertões, que evidenciou de forma monumental a vida no sertão brasileiro; e a "progressista", que entendeu a formação e a resistência do Arraial como "baluarte da luta pela terra e conferiu aos sertanejos do Conselheiro uma consciência razoável do sentido e da grandeza de seus projetos" (p.241). Segundo Hermann, o poder interpretativo resultante do cruzamento dessas duas visões foi muito tímido no filme, que claramente optou pela versão euclidiana. A autora aponta a riqueza da intervenção ficcional realizada pelo autor (o "personagem de cinco cabeças", representado pela família composta por pai, mãe e três filhos) e a esmerada produção, mas faz ressalvas quanto à representação construída sobre o beato Antônio Conselheiro. O filme, ao reforçar aspectos míticos e conferir certo isolacionismo à atuação do Conselheiro, pode contribuir para a construção de uma visão um tanto estereotipada dos acontecimentos, deixando francamente de lado visões mais progressistas sobre a atuação desses sertanejos (Hermann, 2001).
} 
Nas aulas observadas, a professora partiu de uma série de ideias pré-concebidas sobre as temáticas abordadas, muitas delas vindas de conteúdos veiculados nos meios de comunicação e do contato com produtos culturais. Quando os estudantes não verbalizavam suas ideias prévias, isto é, não correspondiam à expectativa de Joana de iniciar a aula dialogando com suas perspectivas, a professora, muitas vezes, construía um cenário inicial articulando informações vindas das mídias, principalmente do jornalismo e do cinema.

Mesmo considerando que a palavra escrita é predominante e pauta a experiência escolar, e que esta é fundamental para os estudantes adquirirem autonomia para ler, interpretar, analisar, localizar, relacionar etc., é importante admitir que há outros elementos e linguagens imprescindíveis para a aquisição de conhecimentos formais. A aula de história acontece a partir de um conjunto de práticas orais, de leitura, de escrita, de posicionamento corporal, de controle ou uso das emoções e da atenção. O domínio sobre o modus operandi das mídias, do cinema e da tevê, a capacidade de pesquisar com eficiência na internet são tarefas igualmente importantes para a construção significativa de conhecimento histórico escolar. Na escola observada, apostas e estranhamentos em torno das mídias se verificam. O investimento deliberado em diferentes linguagens, com atenção aos seus mecanismos próprios de produção de mensagens, pode resultar em maiores possibilidades de aprendizagem histórica significativa. Mas até que ponto a lógica da escola viabiliza trabalhos desse tipo? Que espaços para a construção de conceitos que auxiliem a compreensão da história existem hoje na instituição escolar? Se a construção do conhecimento histórico na escola está atravessada pela lógica da mídia, em quais pontos a lógica da escola está desafiada? Essas são algumas questões que merecem destaque para a compreensão dos atravessamentos simbólicos entre mídia, conhecimento histórico e cultura escolar, essenciais para a promoção de projetos formativos de mídia-educação

\section{REFERÊNCIAS}

FRONZA, M. A intersubjetividade e a verdade na aprendizagem histórica de jovens estudantes a partir das histórias em quadrinhos. Tese de Doutorado, Curitiba, UFPR, 2012 
HAYLES, K. N. Hyper and Deep Attention: The Generational Divide in Cognitive Mode. Profession, 2007, pp. 187-199 (13).

HERMANN, J. Imagens de Canudos. In: SOARES, M.C., FERREIRA, J. (org.) A História vai ao Cinema: vinte filmes brasileiros comentados por historiadores. Rio de Janeiro, Record, 2001.

HJARVARD, S. Midiatização: teorizando a mídia como agente de mudança social e cultural. Matrizes, v.5, n.2, 2012.

ROCHA, H. A. B. O lugar da linguagem no ensino de História: entre a oralidade e a escrita. Niterói: PPGFE-UFF, 2006 (Tese de Doutorado em Educação).

SÁ, P.T. Conhecimento histórico e mídia em uma escola da Rede Municipal de Ensino do Rio de Janeiro. Rio de Janeiro, Departamento de Educação, PUC-Rio, 2016 (Tese de Doutorado em Educação).

SILVERSTONE, R. Por que estudar mídia? São Paulo, Edições Loyola, 2002. 